\title{
Myocarditis: an uncommon manifestation of dengue fever infection
}

\author{
Christian David Adams, ${ }^{1}$ Daniel Syro, ${ }^{2}$ Juan Felipe Llano, ${ }^{2}$ Juan Felipe Betancur (1) 3,4
}

${ }^{1}$ Division of Cardiology, Fundación Valle del Lili, Cali, Colombia

${ }^{2}$ Department of Emergency Medicine, Clinica Medellin Grupo Quirónsalud, Medellin, Colombia

${ }^{3}$ Department of Internal Medicine, Clinica Medellin Grupo Quirónsalud, Medellin, Colombia

${ }^{4}$ Department of Internal Medicine, Salud Sura, Medellin, Colombia

\section{Correspondence to} Dr Juan Felipe Betancur; juanfebp@hotmail.com

Accepted 19 January 2021
Check for updates

(C) BMJ Publishing Group Limited 2021. No commercial re-use. See rights and permissions. Published by BMJ.

To cite: Adams CD, Syro D, Llano JF, et al. BMJ Case Rep 2021;14:e241569. doi:10.1136/bcr-2021241569

\section{DESCRIPTION}

A 30-year-old man with a history of non-Hodgkin's lymphoma presented with oppressive chest pain radiating to the left arm. ECG revealed sinus rhythm $(60 \mathrm{bpm})$, and non-specific $\mathrm{T}$ wave changes in leads DI and DII, without ST-segment elevation; troponin I level was elevated: $6.39 \mathrm{ng} / \mathrm{mL}$ (normal value $<0.120 \mathrm{ng} / \mathrm{mL}$ ). Echocardiography showed left ventricle ejection fraction of $58 \%$, no systolic or diastolic disturbances, valve abnormalities or other lesions. He was referred to our institution with a suspicion of a non-ST segment elevation myocardial infarction. Due to this unusual diagnosis at his age, other causes of chest pain were ruled out. In a new interview, the patient indicated that he had had fever and diffuse myalgias after a trip to an endemic dengue region 2 weeks before. Thus, dengue-specific antibodies were ordered, which disclosed reactive IgM, negative IgG and negative non-structural protein 1.

Gadolinium cardiac MRI (CMRI) showed normal cardiac chamber size, preserved right ventricular ejection fraction and left ventricular systolic function in the lower limit (52\%), with diffuse hypokinesis. Pericardial effusion and changes in pericardial thickness were absent. There were

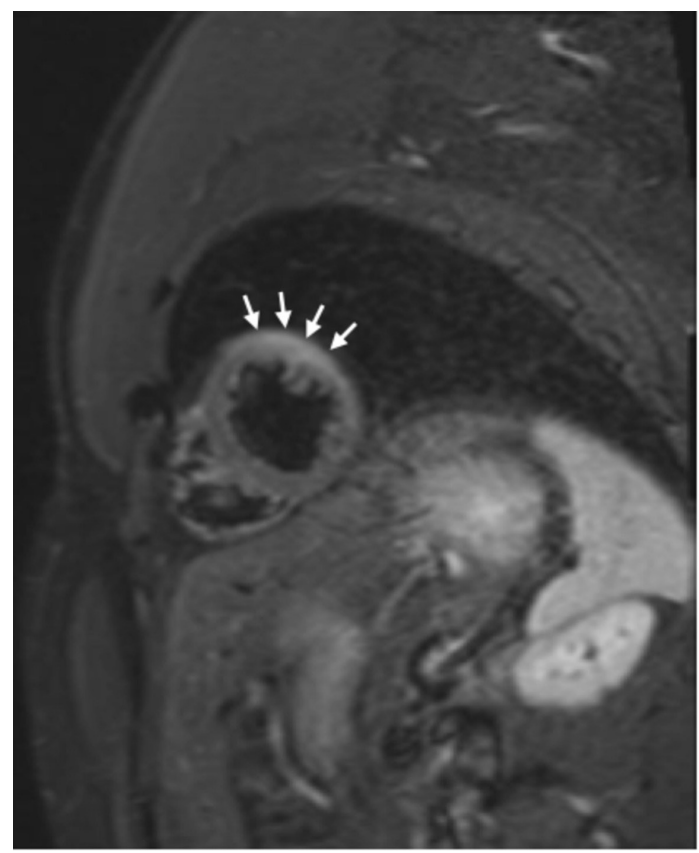

Figure 1 T2-weighted oedema image. An increase in the signal intensity in the mid-ventricular and apical epicardium, mainly towards the anterior and lateral wall, is observed (arrows).

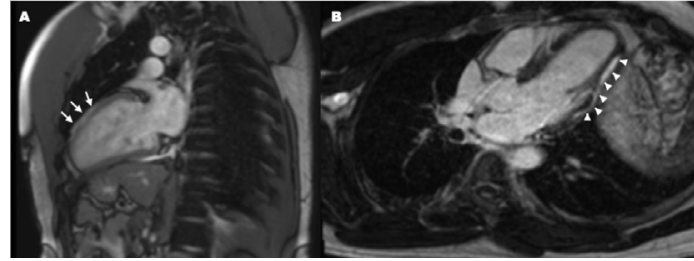

Figure 2 (A) Gadolinium-enhanced T1-weighted image. A large area of early subepicardial gadolinium enhancement of the lateral wall of the left ventricle is noted. There is no increase in the global myocardial early gadolinium enhancement ratio between myocardium and skeletal muscle (arrows). (B) inversion recoverygadolinium-enhanced T1-weighted image. A focal lesion with non-ischaemic regional distribution in the mid-ventricular and apical subepicardium is seen (arrow heads).

findings compatible with myocarditis in the tissue characterisation and gadolinium enhancement sequences (figures 1, 2A and B). The evolution of the patient was uneventful, and he recovered completely.

Dengue fever is caused by any of the four serotypes of the dengue virus transmitted by the mosquito species Aedes aegypti and Aedes albopictus. It is a rapidly spreading mosquito-borne viral disease, endemic in some countries with a high prevalence rate. WHO (2009) classifies dengue into two major categories: dengue (with or without warning signs) and severe dengue. Significant organ involvement (liver, central nervous system, heart or other organs) is present in severe dengue cases.

Cardiac manifestations of dengue include pericardial effusions, myocarditis, atrioventricular block, ectopic ventricular beats and atrial fibrillation. ${ }^{1}$ The prevalence of myocarditis in hospitalised dengue patients is $11.28 \%$. It is higher in patients with non-severe dengue with warning signs and severe dengue $(46.6 \%)$, than in patients with nonsevere dengue without warning signs $(9.72 \%) .{ }^{2}$ In a patient who died of myocarditis, Salgado et al found a direct dengue virus invasion of cardiomyocytes, myocardial interstitial cells and endothelial cells, along with increased proinflammatory markers, and abnormal calcium homoeostasis. ${ }^{3}$ Usually, dengue myocarditis is resolved with supportive care..$^{4-6}$ Some deaths have been reported, mostly when a prompt diagnosis was not made. ${ }^{35}$

CMRI is vital for an earlier myocarditis diagnosis in dengue fever infection, applying diagnostic criteria that target tissue inflammation-Lake Louise Consensus Criteria. These criteria are compatible with myocardial inflammation —with a 
sensitivity of $76 \%$ and specificity of $96 \%$-if two out of three are met: (1) Regional or global myocardial signal intensity increase in T2-weighted oedema images; (2) increased global myocardial early gadolinium enhancement ratio between myocardium and skeletal muscle in gadolinium-enhanced T1-weighted images and (3) at least one focal lesion with non-ischaemic regional distribution in inversion recovery-prepared gadolinium-enhanced T1-weighted images. ${ }^{7}$

\section{Learning points}

Young patients with chest pain should prompt the physician to rule out other diagnoses besides myocardial ischaemic infarction.

- Myocarditis caused by dengue is infrequent but can be lifethreating in some cases.

- Lake Louise Consensus Criteria should be assessed in MRI to establish the diagnosis of myocarditis.

Acknowledgements We thank Dr Luis V Syro for the revision and corrections made to the article.

Contributors Category 1: Conception and design of study: JFB, CDA, DS, JFL. Recollection of data: JFL, CDA, DS, JFL. Analysis and/or interpretation of data: JFB, CDA, DS and JFL. Category 2: Drafting the manuscript: JFB, CDA, DS and JFL. Revising the manuscript critically for important intellectual content: JFB, CDA, DS and
JFL. Category 3: Approval of the version of the manuscript to be published: JFB, CDA, DS and JFL.

Funding The authors have not declared a specific grant for this research from any funding agency in the public, commercial or not-for-profit sectors.

Competing interests None declared.

Patient consent for publication Obtained.

Provenance and peer review Not commissioned; externally peer reviewed.

\section{ORCID iD}

Juan Felipe Betancur http://orcid.org/0000-0003-1331-6605

\section{REFERENCES}

1 Gulati S, Maheshwari A. Atypical manifestations of dengue. Trop Med Int Health 2007:12:1087-95.

2 Li Y, Hu Z, Huang Y, et al. Characterization of the myocarditis during the worst outbreak of denque infection in China. Medicine 2016;95:e4051.

3 Salgado DM, Eltit JM, Mansfield K, et al. Heart and skeletal muscle are targets of dengue virus infection. Pediatr Infect Dis J 2010;29:238-42.

4 Zea D, Foley K, Carey J. Myocarditis in a traveler returning from the Dominican Republic: an unusual presentation of dengue fever. Am J Trop Med Hyg 2014:91:156-8.

5 Lee C-H, Teo C, Low AF. Fulminant dengue myocarditis masquerading as acute myocardial infarction. Int J Cardiol 2009;136:e69-71. Aug 21.

6 Lee I-K, Lee W-H, Liu J-W, et al. Acute myocarditis in dengue hemorrhagic fever: a case report and review of cardiac complications in dengue-affected patients. Int I Infect Dis 2010;14:e919-22.

7 Friedrich MG, Sechtem U, Schulz-Menger J. International consensus group on cardiovascular magnetic resonance in myocarditis. cardiovascular magnetic resonance in myocarditis: a JACC white paper. J Am Coll Cardiol 2009;53:1475-87.

Copyright 2021 BMJ Publishing Group. All rights reserved. For permission to reuse any of this content visit https://www.bmj.com/company/products-services/rights-and-licensing/permissions/

BMJ Case Report Fellows may re-use this article for personal use and teaching without any further permission.

Become a Fellow of BMJ Case Reports today and you can:

- Submit as many cases as you like

- Enjoy fast sympathetic peer review and rapid publication of accepted articles

- Access all the published articles

Re-use any of the published material for personal use and teaching without further permission

Customer Service

If you have any further queries about your subscription, please contact our customer services team on +44 (0) 2071111105 or via email at support@bmj.com.

Visit casereports.bmj.com for more articles like this and to become a Fellow 